UDC 615.281:615.454

https://doi.org/10.24959/cphj.19.1491

\author{
V. I. Hrytsenko, L. S. Kienko, L. O. Bobrytska
}

National University of Pharmacy

\title{
THE STUDY OF THE ANTIMICROBIAL ACTIVITY OF A SOFT DOSAGE FORM WITH THE ANTIVIRAL EFFECT
}

Nowadays there is a tendency towards the spread of viral diseases that cause significant complications to human health. Therefore, the question of creating new drugs that have a high antiviral effect is topical.

Aim. To study the antimicrobial activity of the pharmaceutical composition with acyclovir and miramistin in a soft dosage form with the antiviral effect.

Materials and methods. The objects of the study were model samples of the soft dosage form containing acyclovir and miramistin in the concentrations of $0.25 \%$ (sample 1), $0.5 \%$ (sample 2), $0.75 \%$ (sample 3). Staphylococcus aureus ATCC 25293, Bacillus subtilis ATCC 6633, Escherichia coli ATCC 25922 and Candida albicans ATCC 885/653 were used as test cultures. The antimicrobial activity of the experimental samples was studied in vitro by the agar diffusion method.

Results. According to the results of the studies it has been found that all samples under research have a wide range of the antimicrobial action in relation to the test strains used (the diameter of the growth inhibition zones of test cultures is 13-26 mm). It has been proven that the culture of the test strain Staphylococcus aureus ATCC 25293 has a higher sensitivity to samples $\mathbf{2}$ and $\mathbf{3}$.

Conclusions. The studies of the antimicrobial activity of the soft dosage form with the antiviral effect in relation to different cultures of microorganisms have been conducted, and the optimal concentration of the active substance - miramistin, $0.5 \%$, has been experimentally substantiated.

Key words: antimicrobial activity; acyclovir; miramistin; soft dosage form

\section{В. І. Гриценко, Л. С. Кієнко, Л. О. Бобрицька}

Національний фармацевтичний університет

Дослідження антимікробної активності м'якої лікарської форми противірусної дії

3 кожним днем поширюється тенденція до розповсюдження вірусних захворювань, які завдають значних ускладнень здоров'ю людини. Тому актуальним $є$ питання створення нових лікарських препаратів, які володіють високою противірусною активністю та при цьому не викликають резистентності.

Мета роботи. Вивчити антимікробну активність фармацевтичної композиції з ацикловіром та мірамістином у вигляді м'якої лікарської форми противірусної дії.

Матеріали та методи. Об’єктами дослідження були модельні зразки м'якої лікарської форми, до складу яких входили ацикловір та мірамістин у концентраціях 0,25 \% (зразок 1), 0,5% (зразок 2), 0,75 \% (зразок 3). В якості тест-культур використовували Staphylococcus aureus ATCC 25293, Bacillus subtilis ATCC 6633, Escherichia coli ATCC 25922 та Candida albicans ATCC 885/653. Антимікробну активність дослідних зразків вивчали in vitro за допомогою методу дифузії в агар.

Результати та їх обговорення. За результатами проведених досліджень встановлено, що всі досліджувані зразки мають широкий спектр антимікробної дії по відношенню до використаних тест-штамів (діаметр зон затримки росту тест-культур складає 13-26 мм). Доведено, що культура тест-штаму Staphylococcus aureus ATCC 25293 має більш високу чутливість до зразків № 2 та № 3.

Висновки. Проведено дослідження антимікробної активності м'якої лікарської форми противірусної дії по відношенню до різних культур мікроорганізмів та експериментально обгрунтовано оптимальну концентрацію діючої речовини мірамістин - 0,5 \%.

Ключові слова: антимікробна активність; ацикловір; мірамістин; м'яка лікарська форма

\section{В. И. Гриценко, Л. С. Киенко, Л. А. Бобрицкая}

Национальный фармацевтический университет

Исследование антимикробной активности мягкой лекарственной формы противовирусного действия

С каждым днем наблюдается тенденция к распространению вирусных заболеваний, которые влекут за собой значительные осложнения здоровью человека. Поэтому актуальным является вопрос создания новых лекарственных препаратов, обладающих высокой противовирусной активностью и при этом не вызывают резистентности.

Цель работы. Изучить антимикробную активность фармацевтической композиции с ацикловиром и мирамистином в виде мягкой лекарственной формы противовирусного действия.

Материалы и методы. Объектами исследования были модельные образцы мягкой лекарственной формы, в состав которых входили ацикловир и мирамистин в концентрациях 0,25 \% (образец 1), 0,5 \% (образец 2), 0,75 \% (образец 3). В качестве тест-культур использовали Staphylococcus aureus ATCC 25293, Bacillus subtilis 
ATCC 6633, Escherichia coli ATCC 25922 и Candida albicans ATCC 885/653. Антимикробную активность исследуемых образцов изучали in vitro с помощью метода диффузии в агар.

Результаты и их обсуждение. За результатами проведенных исследований установлено, что все исследуемые образцы имеют широкий спектр антимикробного действия по отношению к использованным тест-штаммам (диаметр зон задержки роста тест-культур составляет 13-26 мм). Доказано, что культура тест-штамма Staphylococcus aureus ATCC 25293 имеет более высокую чувствительность к образцам № 2 и № 3.

Выводы. Проведено исследование антимикробной активности мягкой лекарственной формы противовирусного действия в отношении различных культур микроорганизмов и экспериментально обоснована оптимальная концентрация действующего вещества мирамистин - 0,5 \%.

Ключевые слова: антимикробная активность; ацикловир; мирамистин; мягкая лекарственная форма

Tn recent years there is a steady tendency towards an increase in the number of viral diseases. These diseases have a negative impact on the quality of life of patients, their psycho-emotional state and also lead to deterioration of the general physiological work of all body systems [1].

The main factors affecting the features of the pathological process is the age and sex of the patient, genetic inheritance, comorbid conditions, nonspecific protection factors (interferon, phagocytes, etc.).

Currently, the main methods of treatment and prevention of viral infections are vaccination and the use of drugs of synthetic origin [2]. It is known that pharmacotherapy with synthetic drugs in most cases is not only an alternative method of treatment, but often the only possible direction of effective control against viral pathologies.

Despite the significant advances in pharmaceutical and medical science and the use of advanced technologies in pharmaceutical production, the arsenal of modern antiviral drugs remains very limited. It should be noted that the pharmaceutical market of Ukraine offers a limited number of drugs for the treatment of many viral diseases or in most cases these drugs are not available et al.

Acyclovir and miramistin are promising pharmaceutical ingredients with a high biological potential to create a multidirectional drug. Acyclovir is a blocker of the viral DNA synthesis. It interacts competitively with viral thymidine kinase and is sequentially phosphorylated to form mono-, di- and triphosphate; the latter inhibits DNA polymerase and stops virus replication. The advantages of acyclovir are high selectivity and low toxicity [3-5].

It is possible to introduce a substance that has the antimicrobial effect into the composition of the drug with the antiviral pharmacological activity in order to prevent development of inflammatory complications. Miramistin has a pronounced antimicrobial activity against grampositive and gram-negative bacteria, fungi, viruses, protozoa. Miramistin molecules hydrophobically interact with lipid membranes of microorganisms, and it leads to fragmentation and destruction of the microbial membrane. It belongs to synthetic substances with low toxicity, has no local irritant, allergic, mutagenic, carcinogenic and embryotoxic actions [6-8]. In connec- tion with the above, it is advisable to use acyclovir in combination with miramistin, which will significantly expand the range of the pharmacological action of the drug developed.

The aim of the work was to study the antimicrobial activity of the pharmaceutical composition with acyclovir and miramistin in the soft dosage form.

\section{Materials and methods}

In order to determine the optimal composition of the pharmaceutical composition the samples of the ointments with the content of acyclovir of $5 \%$ and the content of miramistin of $0.25 \%$ (sample 1 ), $0.5 \%$ (sample 2), $0.75 \%$ (sample 3 ) were prepared.

The experimental samples were stored at a temperature of $5 \pm 3{ }^{\circ} \mathrm{C}$. All studies were performed under aseptic conditions using a laminar box (biological safety cabinet AC2-4E1 "Esco", Indonesia).

The following pure cultures were used as test cultures: gram-positive microorganisms Staphylococcus aureus ATCC 25293, spore culture Bacillus subtilis ATCC 6633, gram-negative culture of Escherichia coli ATCC 25922. The antifungal action was found in relation to the yeast-like fungus of the genus Candida - Candida albicans ATCC 885/653 $[9,10]$. During the experiments one-day suspensions of bacterial microorganisms in the physiological solution and a two-day culture of yeast-like fungus were used. The microbial load was $10^{7}$ colony-forming units of microorganisms in $1 \mathrm{ml}$ of the nutrient medium $(\mathrm{CFU} / \mathrm{ml})$.

The antimicrobial activity of the experimental samples was studied in vitro by the agar diffusion method ("wells" method). This method is based on the ability of active substances to diffuse into the agar medium previously inoculated with microorganism cultures.

To Petri dishes $10 \mathrm{ml}$ of the melted "hungry" agar was added. After fixing the lower layer of agar on its surface at the same distance from each other and from the edge of the dish 4 sterile steel thin-walled cylinders (the inner diameter $-6.0 \pm 0.1 \mathrm{~mm}$, the height $-10.0 \pm 0.1 \mathrm{~mm}$ ) were placed. Around the cylinders the upper layer was filled, it contained $14 \mathrm{ml}$ of agar melted and cooled to $45-48{ }^{\circ} \mathrm{C}$, mixed with the inoculated dose of the test microorganism. When working with bacterial cultures meat-peptone 
The results of the antimicrobial activity of the samples

\begin{tabular}{|c|c|c|c|c|}
\hline \multirow{3}{*}{$\begin{array}{c}\text { Sample } \\
\text { (for } 100,0 \mathrm{~g} \text { of } \\
\text { ointment) }\end{array}$} & \multicolumn{4}{|c|}{ Cultures of microorganisms } \\
\hline & $\begin{array}{c}\text { S. aureus } \\
\text { ATCC } 25293\end{array}$ & $\begin{array}{l}\text { B. subtilis } \\
\text { ATCC } 6633\end{array}$ & $\begin{array}{c}\text { E. coli } \\
\text { ATCC } 25922\end{array}$ & $\begin{array}{c}\text { C. albicans } \\
\text { ATCC } 885 / 653\end{array}$ \\
\hline & \multicolumn{4}{|c|}{ Diameters of the growth inhibition zones of microorganisms, $\mathrm{mm}$} \\
\hline Sample $1-0.25 \mathrm{~g}$ & $21.6 \pm 0.5$ & $21.2 \pm 0.4$ & $19.6 \pm 0.5$ & $13.4 \pm 0.5$ \\
\hline Sample $2-0.5 \mathrm{~g}$ & $26.2 \pm 0.4$ & $24.6 \pm 0.5$ & $23.4 \pm 0.5$ & $16.6 \pm 0.5$ \\
\hline Sample $3-0.75 \mathrm{~g}$ & $26.4 \pm 0.5$ & $24.6 \pm 0.5$ & $23.6 \pm 0.5$ & $16.8 \pm 0.4$ \\
\hline
\end{tabular}

agar was used for the second layer, and while working with a yeast-like fungus Sabouraud agar was used. After cooling the top layer the cylinders were removed with sterile tweezers, and the test samples were added into the cells obtained until complete filling. Petri dishes were kept for 30-40 min at room temperature and placed in a thermostat bacterial cultures at a temperature of $32.5 \pm 2.5^{\circ} \mathrm{C}$ for $18-24 \mathrm{~h}$, and the culture of yeast-fungus at a temperature of $22.5 \pm 2.5^{\circ} \mathrm{C}$ for $48 \mathrm{~h}$.

The results were recorded by measuring the growth inhibition zone of microorganisms, including the diameter of the cells. The measurements were carried out with an accuracy of $1 \mathrm{~mm}$; the focus was on the complete absence of visible growth.

The diameter of the growth inhibition zone of microorganisms characterized the antimicrobial activity of the experimental samples:

- the growth inhibition zones with the diameter of up to $10 \mathrm{~mm}$ were assessed as the insensitivity of microorganisms to the samples introduced into the cell;

- the growth inhibition zones with the diameter of 11-15 mm were assessed as a weak sensitivity of the culture to the effective concentration of the antimicrobial substance;

- the growth inhibition zones with the diameter of 16-25 mm were characterized as an indicator of the sensitivity of the microorganism to the test samples;

- the growth inhibition zones with the diameter exceeded $25 \mathrm{~mm}$ indicated a high sensitivity of microorganisms to the samples of the soft dosage form.

\section{Results and discussion}

The studies of the antimicrobial properties of model samples of the ointments in relation to different cultures of microorganisms were conducted. The results of the studies are given in Table.

As can be seen from the data of Table, all samples studied have a wide range of the antimicrobial action in relation to the test strains used: bacterial gram-positive (Staphylococcus aureus ATCC 25293 and spore culture Bacillus subtilis ATCC 6633), gramnegative (Escherichia coli ATCC 25922) cultures, as well as the fungicidal action against yeast-like fungus of the genus Candida albicans ATCC 885/653.

It should be noted that sample 2 containing $0.5 \%$ of miramistin is more active compared to sample $\mathbf{1}$ ( $0.25 \%$ of miramistin) in relation to all test strains of microorganism cultures: Staphylococcus aureus $26.2 \pm 0.4 \mathrm{~mm}$ and $21.6 \pm 0.5 \mathrm{~mm}$, Bacillus subtilis $24.6 \pm 0.5 \mathrm{~mm}$ and $21.2 \pm 0.4 \mathrm{~mm}$, Escherichia coli $23.4 \pm 0.5 \mathrm{~mm}$ and $19.6 \pm 0.5 \mathrm{~mm}$ and Candida albicans $16.6 \pm 0.5 \mathrm{~mm}$ and $13.4 \pm 0.5 \mathrm{~mm}$, respectively. The results of the experiments showed that the increase in samples of miramistin to $0.75 \%$ (sample 3 ) practically did not increase the antimicrobial activity compared to the activity of sample $2(0.5 \%)$.

Thus, the soft dosage form comprising such active pharmaceutical ingredients as acyclovir and miramistin has the antimicrobial activity against all test strains used, namely Staphylococcus aureus ATCC 25293, Bacillus subtilis ATCC 6633, Escherichia coli ATCC 25922 and Candida albicans ATCC 885/653.

\section{CONCLUSIONS}

1. The study of the antimicrobial activity of the soft dosage form with the antiviral effect with acyclovir and miramistin has been conducted.

2. Based on the results of the experiment it has been proven that the sample of the ointment studied with the miramistin content of $0.5 \%$ is the most active in relation to all test strains of microorganism cultures. The increase of the amount of miramistin to $0.75 \%$ does not significantly affect the antimicrobial activity of the model samples.

3 . The results of the study of the antimicrobial activity of the pharmaceutical composition in the form of the soft dosage form indicate the feasibility of development of a new drug with the antiviral effect.

Conflict of interests: authors have no conflict of interests to declare. 


\section{References}

1. Дмитриевский, Д. И. Технологические аспекты к разработке лекарственного препарата противовирусного действия / Д. И. Дмитриевский, Л. А. Бобрицкая // Зб. наук. праць співробітників НМАПО ім. П. Л. Шупика. - К., 2009. - Вип. 18, кн. 3. - С. 335-340.

2. Рублева, О. В. Герпесвирусная инфекция и противовирусные препараты в практике врача. К вопросу о терапии и профилактике вирусных инфекций / О. В. Рублева // Рус. мед. журн. - 2012. - Т. 20, № 11. - С. 571-574.

3. Казанцева, И. А. Эффективность местного применения ацикловира в лечении герпеса губ у детей / И. А. Казанцева, Н. Н. Казанцева // Вестник ВолгГМУ. - 2016. - Вып. 4 (60). - С. 96-98.

4. Коровина, А. Н. Поиск ингибиторов репликации вируса герпеса: 30 лет после ацикловира / А. Н. Коровина, М. К. Куханова, С. Н. Кочетков // BIOTECHNOLOGIAACTA. - 2013. - Вып. 6 (4). - С. 78-85.

5. Acyclovir and transmission of HIV-1 from persons infected with HIV-1 and HSV-2 / C. Celum, A. Wald, J. R. Lingappa et al. // N. Engl. J. Med. - 2010. - Vol. 362, № 4. - P. 427-439. https://doi.org/10.1056/NEJMoa0904849

6. Дунаевский, А. М. Клиническое обоснование использования препарата Мирамистин в терапии инфекционно-воспалительных заболеваний респираторной системы: обзор литературы / А. М. Дунаевский, И. М. Кириченко // Поликлиника. - 2013. - № 5. - С. 6-12.

7. Кириченко, И. М. Использование препарата Мирамистин® при инфекционной патологии в гинекологии / И. М. Кириченко // Поликлиника. - 2013. - № 6. - С. 100-102.

8. Изучение противовирусных свойств мирамистина in vitro в отношении вируса простого герпеса 1-го и 2-го типов / И. Ф. Баринский, Л. М. Алимбарова, Н. А. Кириченко и др. // Дерматовенерол. и дерматокосметол. - 2012. - № 2. - С. $28-31$.

9. Вивчення специфічної активності антимікробних лікарських засобів / Ю. Л. Волянський, І. С. Гриценко, В. П. Широбоков та ін. - К., 2004. - 38 с.

10. Державна фармакопея України: в 3 т. / Державне підприємство «Український науковий фармакопейний центр якості лікарських засобів». - 2-е вид. - Х. : Державне підприємство «Український науковий фармакопейний центр якості лікарських засобів», 2015. - Т. 1. - 1128 с.

\section{References}

1. Dmytryevskyi, D. Y., Bobrytskaia, L. A. (2009). Zbirnyk naukovykh prats spivrobitnykiv NMAPO im. P. L. Shupyka,18(3), 335340. Kyiv.

2. Rubleva, O. V. (2012). RMZh, 20(11), 571-574.

3. Kazantseva, I. A., Kzantseva, N. N. (2016). Vestnik VolgGMU, 4 (60), 96-98.

4. Korovina, A. N., Kukhanova, M. K., Kochetkov, S. N. (2013). BIOTECHNOLOGIAACTA, 6 (4), 78-85.

5. Celum, C., Wald, A., Lingappa, J. R., Magaret, A. S., Wang, R. S. (2010). Acyclovir and transmission of HIV-1 from persons infected with HIV-1 and HSV-2. The new England journal of medicine, 362 (4), 427-439. https://doi.org/10.1056/NEJMoa0904849

6. Dunayevskiy, A. M., Kirichenko, I. M. (2013). Poliklinika, 5, 6-12.

7. Kirichenko, I. M. (2013). Poliklinika, 6, 100-102.

8. Barinskiy, I. F., Alimbarova, L. M., Kirichenko, N. A., Svistov, V. V., Smirnov, I. V., Krivoshein, Yu. S. (2012). Dermatovenerologiya i dermatokosmetologiya, 2, 28-31.

9. Volianskyi, Yu. L., Hhrytsenko, I. S., Shyrobokov, V. P. (2004). Vyvchennia spetsyfichoi aktyvnosti protymikrobnykh likarskykh zasobiv. Kyiv, 38.

10. Derzhavna Farmakopeia Ukrainy. (2015). Ukrainskyi naukovyi farmakopeinyi tsentr yakosti likarskykh zasobiv, 1. Kharkiv, 1128.

Information about authors / Відомості про авторів / Информация об авторах

Hrytsenko V. I., Doctor of Pharmacy (Dr. habil), professor of the Department of Industrial Technology of Drugs, National University of Pharmacy. E-mail: nika.gritsenko@gmail.com

Гриценко В. I., доктор фармацевтичних наук, професор кафедри заводської технології ліків, Національний фармацевтичний університет. E-mail: nika.gritsenko@gmail.com

Гриценко В. И., доктор фармацевтических наук, профессор кафедры заводской технологии лекарств, Национальный фармацевтический университет. E-mail: nika.gritsenko@gmail.com

Kienko L. S., postgraduate student of the Department of Industrial Technology of Drugs, National University of Pharmacy.

E-mail: kienko.pharm@gmail.com

Кієнко Л. C., аспірант кафедри заводської технології ліків, Національний фармацевтичний університет.

E-mail: kienko.pharm@gmail.com

Киенко Л. C., аспирант кафедры заводской технологии лекарств, Национальный фармацевтический университет.

E-mail: kienko.pharm@gmail.com

Bobrytska L. O., Doctor of Pharmacy (Dr. habil), professor of the Department of Industrial Technology of Drugs, National University of Pharmacy. E-mail: lora2015dm@gmail.com

Бобрицька Л. О., доктор фармацевтичних наук, професор кафедри заводської технології ліків, Національний фармацевтичний університет. E-mail: lora2015dm@gmail.com

Бобрицкая Л. А., доктор фармацевтических наук, профессор кафедры заводской технологии лекарств, Национальный фармацевтический университет. E-mail: lora2015dm@gmail.com

Адреса для листування: 61002, м. Харків, вул. Пушкінська, 53, кафедра заводської технології ліків НФаУ. Тел. +380572678852.

E-mail: ztl@nuph.edu.ua

Mailing address: 53, Pushkinska str., Kharkiv, 61002, Ukraine, National University of Pharmacy, Department of Industrial Technology of Drugs, +380572678852. E-mail: ztl@nuph.edu.ua

Адрес для переписки: 61002, г. Харьков, ул. Пушкинская, 53, кафедра заводской технологии лекарств НФаУ. Тел. +380572678852.

E-mail: ztl@nuph.edu.ua 